Article

\title{
Biopolymer Coatings as Alternative to Modified Atmosphere Packaging for Shelf Life Extension of Minimally Processed Apples
}

\author{
Stefania Volpe ${ }^{1}$, Silvana Cavella ${ }^{2}$ and Elena Torrieri ${ }^{2, * \mathbb{D}}$ \\ 1 Centre of Food innovation and Development in the Food Industry, Via Università 100, \\ 80055 Portici (NA), Italy \\ 2 Department of Agricultural Science, Via Università 133, 80055 Portici (NA), Italy \\ * Correspondence: elena.torrieri@unina.it
}

Received: 16 August 2019; Accepted: 4 September 2019; Published: 6 September 2019

check for updates

\begin{abstract}
The effect of caseinate/chitosan blend on the shelf life of minimally processed apples was studied. In the first phase of the work, the effect of the biopolymer coating on the respiration rate of the minimally processed apples was studied as function of gas composition $\left(5 \%, 10 \%, 21 \%\right.$ of $\mathrm{O}_{2}$ with $\mathrm{N}_{2}$ as balance at $5{ }^{\circ} \mathrm{C}$ ) and temperature $\left(5{ }^{\circ} \mathrm{C}, 10{ }^{\circ} \mathrm{C}\right.$ at $5 \%$ of $\mathrm{O}_{2}$ with $\mathrm{N}_{2}$ as balance). In the second phase, the shelf life of the packed product was studied during storage at $5{ }^{\circ} \mathrm{C}$. The gas composition $\left(\mathrm{O}_{2} \%-\mathrm{CO}_{2} \%\right)$ in the package headspace, relative humidity, $\mathrm{pH}$, hardness, color and antioxidant capacity of the product were monitored after $0,1,4,7,11$, and 14 days. The coating effectively reduced respiration rate of the product when oxygen was over $10 \%$. In the presence of the coating, the reduction of oxygen did not affect the respiration rate. At $5 \%$ of $\mathrm{O}_{2}$, the respiration rate decreased by $50 \%$ by changing the temperature from $10{ }^{\circ} \mathrm{C}$ to $5{ }^{\circ} \mathrm{C}$. Shelf life study showed that the chitosan-caseinate coating was able to preserve the mechanical properties and the antioxidant capacity of the product during storage by increasing the shelf life by 7 days to 11 days at $5{ }^{\circ} \mathrm{C}$.
\end{abstract}

Keywords: chitosan; sodium caseinate; respiration rate; mechanical properties; antioxidant capacity; minimally processed apple

\section{Introduction}

Fruits are key elements of a healthy and balanced diet, providing humans with essential nutrients and bioactive compounds, including vitamins, organic acid, minerals, fiber, and polyphenols. According to the World Health Organization (WHO), to eat plenty of fruit and vegetables (F\&V) is one of the 5 keys to a healthy diet. People whose diets are rich in F\&V have a significantly lower risk of obesity, heart disease, stroke, diabetes, and certain types of cancer [1]. A wide variety of minimally processed fruits and vegetables $(\mathrm{F} \& \mathrm{~V})$ products has been offered on the market, resulting in an increased consumption and consequently intake of fresh F\&V, benefitting the agrifood economy and human well-being. Minimally processed apples are one of the most predominant fruit in the market. Although minimal processing (MP) methods, such as washing, cutting, and modified atmosphere packaging (MAP), have been demonstrated to preserve the freshness of the products, the shelf life of $\mathrm{F} \& \mathrm{~V}$ is still limited $\left(5-7\right.$ days at $\left.4-5{ }^{\circ} \mathrm{C}\right)$. The quality deterioration of minimally processed apples depends on increased respiration, cut-surface browning, softening, and microbial contamination [2-4]. Enzymatic browning is one of the most important reactions occuring in many fresh-cut fruits and vegetables. It results from oxidation of phenolic compounds catalyzed by polyphenol oxidase (PPO) followed by non-enzymatic spontaneous polymerization of obtained quinones to brown pigments. To control this phenomenon, antioxidant compounds, including ascorbic acid, cysteine and glutathione, 
acidulants, and chelating agents have been used in the general fresh-cut food industry and maintaining the commercial value of fresh cut products [5-8]. Moreover, calcium chloride has been used in combination with antioxidant as a firming agent for fruit tissues since it reacts with pectic acid in the cell wall to form calcium pectate, which strengthens molecular bonding between constituents of cell wall [9]. In a previous work, an antioxidant washing solution based on ascorbic acid, citric acid, and calcium chloride has been optimized to preserve the color of minimally processed apples [10]. A way to further prolong product shelf life is to use edible coating. Coatings create a modification of the atmosphere surrounding the fruit, acting as semipermeable barriers that control gas exchange, reduce water loss, and maintain tissue firmness [11]. Developments in packaging technology and edible coatings for foods have shown promising results in extending the shelf-life of fresh-cut fruits and vegetables [12-18]. Coating based on tapioca starch, chitosan, and alginate in combination with antioxidant additive has been used to improve the shelf life of minimally processed apples [19-21]. Until recently, there has been little research that investigated the effect of the combination of biopolymer coating and anti-browning agents for minimally processed products to inhibit enzymatic browning. A combination of carboxymethyl cellulose and ascorbic acid seemed to have a synergistic effect for control of surface browning of fresh-cut apple during storage [22]. In addition, the effect of edible coatings in combination with anti-browning agents on fresh-cut 'Bravo de Esmolfe' apple has been studied [23] and it was reported that based on general and sensory quality characteristics, fresh-cut apples appeared to be better preserved with alginate coating $(2 \%)$ enriched with eugenol $(0.1 \%)$ plus dipping in ascorbic acid $0.1 \%$. Chitosan $(1 \%)$ and ascorbic acid (5\%) coating successfully extended the cold storage period for 7 days in fresh-cut apples by maintaining the browning level and preserving microbial and chemical quality [24]. In a previous work, the composition of chitosan/caseinate coating to be applied on minimally processed apples were optimized and its use in combination with an antioxidant treatment based with ascorbic acid, citric acid, and calcium chloride was studied. A blend obtained by mixing $2 \%$ of chitosan and $4 \%$ of sodium caseinate at ratio 1:1 were able to reduce the respiration rate of the product in air. Moreover, the blend in combination with the antioxidant treatment was the only able to preserve the color of the product up to 7 days at $5{ }^{\circ} \mathrm{C}$ [25]. Modified atmosphere packaging is normally used for extending the shelf life of minimally processed product. Until recently, there has been little research that investigated the combined effect of biopolymer coating and gas composition. Thus, the objective of the work was to evaluate the effect of biopolymer coatings and gas composition on product respiration rate. On the base of the results product has been packed by using the best gas composition and the quality of the product was evaluated during storage at $5{ }^{\circ} \mathrm{C}$ for 14 days.

\section{Materials and Methods}

\subsection{Preparation of Film Forming Solutions}

The chitosan $(\mathrm{CH})$ solution $(2 \%)$ was prepared by weighing $2 \mathrm{~g}$ of chitosan in $100 \mathrm{~mL}$ of $1 \%$ acetic acid solution $(v / v)$ and stirred for $16 \mathrm{~h}$. The sodium caseinate solution (SC) $(4 \%)$ was prepared by weighing $4 \mathrm{~g}$ of SC in $100 \mathrm{~mL}$ of PBS buffer and meanwhile agitated with a magnetic stirrer for $4 \mathrm{~h}$. Blend solution $(\mathrm{SC} / \mathrm{CH}=2)$, was prepared by adding drop wise the solution of $\mathrm{SC}$ to $\mathrm{CH}$ with 1:1 ratio. An aliquot of glycerol was added to obtain a glycerol/total solids ratio equal to 0.1 .

\subsection{Coating Application}

Apples were selected for uniform size and appearance, without damages and gently washed with tap water for $3 \mathrm{~min}$. Then, apples were peeled and cut in 16 slices and placed in an anti-browning solution (1\% citric acid, $1 \%$ ascorbic acid, $1 \%$ calcium chloride) for two minutes. Then, samples were immersed in the biopolymer solution for $1 \mathrm{~min}$. Coated and uncoated apple slices were put on a grid and allowed to dry into an air tunnel (Armfield tray drier, Ringwood, Hampshire, UK) at $30{ }^{\circ} \mathrm{C}$ for $40 \mathrm{~min}$. 


\subsection{Respiration Rate Measurement}

$\mathrm{O}_{2}$ consumption $\left(\mathrm{R}_{\mathrm{O}_{2}}\right)$ and $\mathrm{CO}_{2}$ production $\left(\mathrm{R}_{\mathrm{CO}_{2}}\right)$ rates of minimally processed apples were measured using a modified closed system [26]. The product $(0.5 \mathrm{~kg})$ were placed in a steel jars $(4000 \mathrm{~mL})$ and conditioned at temperature test. The temperature and relative humidity inside the jar were monitored by means of a data logger (Escort Data Login Systems LTD, Modena, Italy).

To measure the respiration rate at equilibrium, samples were conditioned for two hours at desired temperature and then the system was closed to start the gas measurements. Analysis were performed at $5{ }^{\circ} \mathrm{C}$ by using gas mixtures containing $5 \%, 10 \%$, and $21 \%$ of oxygen (nitrogen as balance), and at $5 \%$ of $\mathrm{O}_{2}$ (nitrogen as balance) in air at $5{ }^{\circ} \mathrm{C}$ and $10^{\circ} \mathrm{C}$.

Gas mixtures were previously produced by a gas distribution firm (SOL S.p.a., Monza, Italy) and packed in certified cylinders. The gas mixture was flushed through a water humidification system at uniform flow rate $\left(1.6 \mathrm{~mL} \cdot \mathrm{s}^{-1}\right)$ before being flushed through the jars containing the product. After equilibrium [26], the inlet and outlet valves were closed and the gas composition was monitored over time with an $\mathrm{O}_{2} / \mathrm{CO}_{2}$ gas analyzer (accuracy of $0.5 \%$ ), equipped with a needle (Check Mate $9900 \mathrm{O}_{2} / \mathrm{CO}_{2}$; Ringsted, Denmark).

The experimental time was $72 \mathrm{~h}$. At constant time intervals $(\Delta \mathrm{t}), 3 \mathrm{~mL}$ of gas mixture were drawn from the jar head space and analyzed using the gas analyzer.

The free volume $\left(V_{f}\right)$ inside the jar was calculated by using Equation (1):

$$
\mathrm{V}_{\mathrm{f}}=\mathrm{V}-\frac{\mathrm{W}}{\rho}
$$

where $\mathrm{V}$ is the volume of the jar $(\mathrm{mL}), \mathrm{W}$ is the weight of the apple $(\mathrm{kg})$, and $\rho$ the apparent density of the apple $\left(810 \mathrm{~kg} \cdot \mathrm{m}^{-3}\right)$.

$\mathrm{R}_{\mathrm{O}_{2}}$ and $\mathrm{R}_{\mathrm{CO}_{2}}$, were determined as follows:

$$
\begin{aligned}
\mathrm{R}_{\mathrm{O}_{2}} & =\left(\frac{\mathrm{dyO}}{\mathrm{dt}}\right) \cdot\left(\frac{\mathrm{V}_{\mathrm{f}}}{\mathrm{W}}\right) \cdot \frac{1}{100} \\
\mathrm{R}_{\mathrm{CO}_{2}} & =\left(\frac{\mathrm{dyCO}}{\mathrm{dt}}\right) \cdot\left(\frac{\mathrm{V}_{\mathrm{f}}}{\mathrm{W}}\right) \cdot \frac{1}{100}
\end{aligned}
$$

where $\mathrm{yO}_{2}$ and $\mathrm{yCO}_{2}$ are the volumetric concentration $(\% v / v)$ of $\mathrm{O}_{2}$ and $\mathrm{CO}_{2}$, respectively, at time $\mathrm{t}(\mathrm{h}), \mathrm{V}_{\mathrm{f}}$ is the free volume $(\mathrm{mL})$ and $\mathrm{W}$ is the weight of the samples $(\mathrm{kg})$. The respiration quotient, $\mathrm{RQ}$, was calculated as follows:

$$
\mathrm{RQ}=\frac{\mathrm{R}_{\mathrm{CO}_{2}}}{\mathrm{R}_{\mathrm{O}_{2}}}
$$

\subsection{Packaging, Storage Condition and Shelf Life Evaluation}

Apple samples $(88 \mathrm{~g})$ were packed in air by using polypropylene pouch $(0.15 \mathrm{~m} \times 0.15 \mathrm{~m})$ and stored at $4{ }^{\circ} \mathrm{C}$ for 14 days. After $0,1,4,7,11$, and 14 days, the head space gas composition $\left(\mathrm{O}_{2} \%-\mathrm{CO}_{2} \%\right)$, the moisture content, the color, the $\mathrm{pH}$, the mechanical properties, and the antioxidant capacity were studied as reported in the following sections.

\subsubsection{Headspace Gas Analysis}

$\mathrm{O}_{2}$ and $\mathrm{CO}_{2}$ concentration $(\% v / v)$ in the package head space were monitored by means of a portable PBI Dansensor A/S (Check Mate $9900 \mathrm{O}_{2} / \mathrm{CO}_{2}$; Ringsted, Denmark) analyzer (accuracy $\pm 0.1 \%$ ), by sampling with a needle $2-3 \mathrm{~mL}$ of gas from the package headspace. 


\subsubsection{Moisture Content, Color and $\mathrm{pH}$}

The moisture content was determined by gravimetric method after storing the samples in an oven at $105{ }^{\circ} \mathrm{C}$ for a time needed to reach a constant weight (ASTM D2974). The moisture content has been calculated as:

$$
\mathrm{UR} \%=\frac{\left(\mathrm{P}_{\mathrm{i}}-\mathrm{P}_{\mathrm{f}}\right)}{\mathrm{P}_{\mathrm{i}}} \cdot 100
$$

where $P_{i}$ is the weight of sample before and $P_{f}$ after the oven storage. Three measurements were performed for each sample.

Color was quantified using a colorimeter tristimolous (Minolta Chroma Meter, model CR-300, Osaka, Japan) having a circular measurement area $(\mathrm{D}=8 \mathrm{~mm})$. The apple sample were positioned on a blank foil and then measured by placed using the colorimetric sensor. The colorimeter was calibrated using a white standard plate. Total color change $(\Delta \mathrm{E})$ was also analyzed (ASTM E1910):

$$
\Delta \mathrm{E}=\sqrt{\left[(\Delta \mathrm{L})^{2}+(\Delta \mathrm{a})^{2}+(\Delta \mathrm{b})^{2}\right]}
$$

Six measurements were performed on each sample.

To measure the apple $\mathrm{pH}$, ten grams of apple sample were blended for $2 \mathrm{~min}$ in $20 \mathrm{~mL}$ of deionized water. The $\mathrm{pH}$ of the slurry was measured at room temperature using a Cyber Scan pHmeter (Eutech Instuments Pte Ltd., Singapore) (ASTM D2244). Four measurements were carried out on each sample.

\subsubsection{Mechanical Properties}

Compression test was performed by using a dynamometer Instron (Instron, Model No 4301, Instron Engineering Corp., Canton, MA, USA) has been used equipped with a $1 \mathrm{kN}$ cell. A cylinder (17 cm diameter $\times 10 \mathrm{~cm}$ high) was obtained from apple sample by using a specific tool. The test was performed at $10 \mathrm{~mm} \cdot \mathrm{min}^{-1}$. From the curve force-strain, the hardness $(\mathrm{N})$ has been calculated as the maximum force required to compress the sample. Five measurements were performed for each sample.

\subsubsection{Antioxidant Capacity}

The antioxidant capacity was studied by evaluation of the free radical- scavenging effect on 1,1-diphenyl-2-picrylhydrazyl (DPPH) radical, according to the method described by Moreira et al. [27] The apple $(5 \mathrm{~g})$ was softly crushed with mortar and pestle and $100 \mu \mathrm{L}$ of the juice was added to $3.9 \mathrm{~mL}$ of methanolic DPPH solution $(100 \mu \mathrm{mol})$. The homogenate was shaken vigorously and kept in darkness for $30 \mathrm{~min}$. Absorption of the samples at $515 \mathrm{~nm}$ against a blank of methanol without the DPPH reagent was spectrophotometrically measured (Jasco V-550 UV/VIS Spectrophotometer, Tokyo, Japan). Antioxidant capacity was related to the scavenging activity of the sample extracts towards the DPPH radical, which can be monitored through the decrease in absorbance once the sample extract has been incorporated to the DPPH solution. The antioxidant capacity (TAA\%) has been expressed as:

$$
\mathrm{TAA} \%=\left(1-\frac{\mathrm{A}_{\mathrm{s}}}{\mathrm{A}_{\mathrm{R}}}\right) \times 100
$$

where $\mathrm{A}$ is the absorbance and $s$ and $\mathrm{R}$ indicated the sample and the reference, respectively. DPPH assays were performed in triplicate.

\subsubsection{Experimental Design and Data Analysis}

A full factory design was used to study the effect of oxygen concentration and coating on the respiration rate of minimally processed apple. There were three levels of oxygen concentration $(5 \%$, $10 \%$, and $21 \%$ ) and two levels of coating (absence-presence) for a total of 6 samples. The effect of temperature was studied by considering two level of temperature $\left(5^{\circ} \mathrm{C}, 10^{\circ} \mathrm{C}\right)$ and two level of coating 
(absence-presence). A full factorial design was also used to study the effect of time and coating on the quality indices of minimally processed apple. There were six levels of storage time $(0,1,4,7,11$, and 14 days) and two levels of coating (absence-presence), thus a total of twelve samples. For all the factors, two-way ANOVA analysis was performed on data to evaluate the effect of independent variables and the interaction effect. Duncan's test and t-test were used to determine significant differences among samples. Significance of differences was defined at $p \leq 0.05$. All statistical analyses were performed using the SPSS software (SPSS Inc. 20.0, Chicago, IL, USA, 2002).

\section{Results and Discussions}

\subsection{Respiration Rate Measurement}

Figure 1 shows the respiration rate expressed as the rate of oxygen consumption of the minimally processed apples as function of oxygen concentration (Figure 1A) and temperature (Figure 1B). For control samples, respiration rate changes from $1.79 \pm 0.02$ to $4.32 \pm 0.06$ as the oxygen increased from $5 \%$ to $21 \%$. The respiratory quotient (RQ) was independent from the oxygen concentration and coating and assumed a constant value of $1.2 \pm 0.1$ for both control and coated samples. ANOVA analysis highlighted a significant effect of both oxygen and coating on the respiration rate of samples with interaction between the two variables $(p<0.05)$. The biopolymer coating had a significant effect on the respiration rate of the samples at $10 \%$ and $21 \%$ of oxygen, whereas no significant effect of coating was highlighted at $5 \%$ of oxygen. Due to the coating, a reduction of respiration rate of $21 \%$ was observed at $10 \%$ of oxygen, whereas at $21 \%$ of oxygen the reduction was of almost $50 \%$. The reduction of respiration rate due to the reduction of oxygen is significant $(p<0.05)$ for control samples whereas oxygen did not have a significant effect for coated samples. This result can be justified by the barrier propriety of the biopolymer coating that induce a reduction of oxygen available at cellular level. When using edible films and coatings on minimally processed fruit and vegetables, a modified atmosphere can be created around the product reducing the respiration rate and, as a result, the metabolic processes [21]. Thus, coated samples stored in air showed a lower respiration rate of samples without coating due to the modification of oxygen at the cellular level. In fact, biopolymer coating based on chitosan and caseinate due to their hydrophilic nature can act as barrier to nonpolar substances such as oxygen or carbon dioxide. Thus, by using the coating technology in combination with refrigeration temperature the utilization of the modified atmosphere packaging technology can be avoided. Similar results were reported by Qui et al. [20], who showed that chitosan coatings were able to reduce the respiration rate of minimally processed apples stored at $25^{\circ} \mathrm{C}$ of almost $50 \%$ due to oxygen barrier properties of chitosan coating. A decrease in the respiration rate was also observed for strawberries coated with chitosan-oleic acid coatings, mandarins coated with hydroxypropylmethylcellulose-beeswax-fatty acid film, plums coated with hydroxypropylmethylcellulose-beeswax film and carrots with caseinate-stearic acid coatings [28].

Figure $1 \mathrm{~B}$ show the combined effect of temperature and coating technology on the respiration rate of samples. As expected, by decreasing the temperature from $10{ }^{\circ} \mathrm{C}$ to $5{ }^{\circ} \mathrm{C}$, the respiration rate of samples was decreased of almost $50 \%$ for both control and coated samples. The effect of temperature was statistically significant whereas the coating effect was not statistically significant at both temperature when the oxygen is at $5 \%$. 

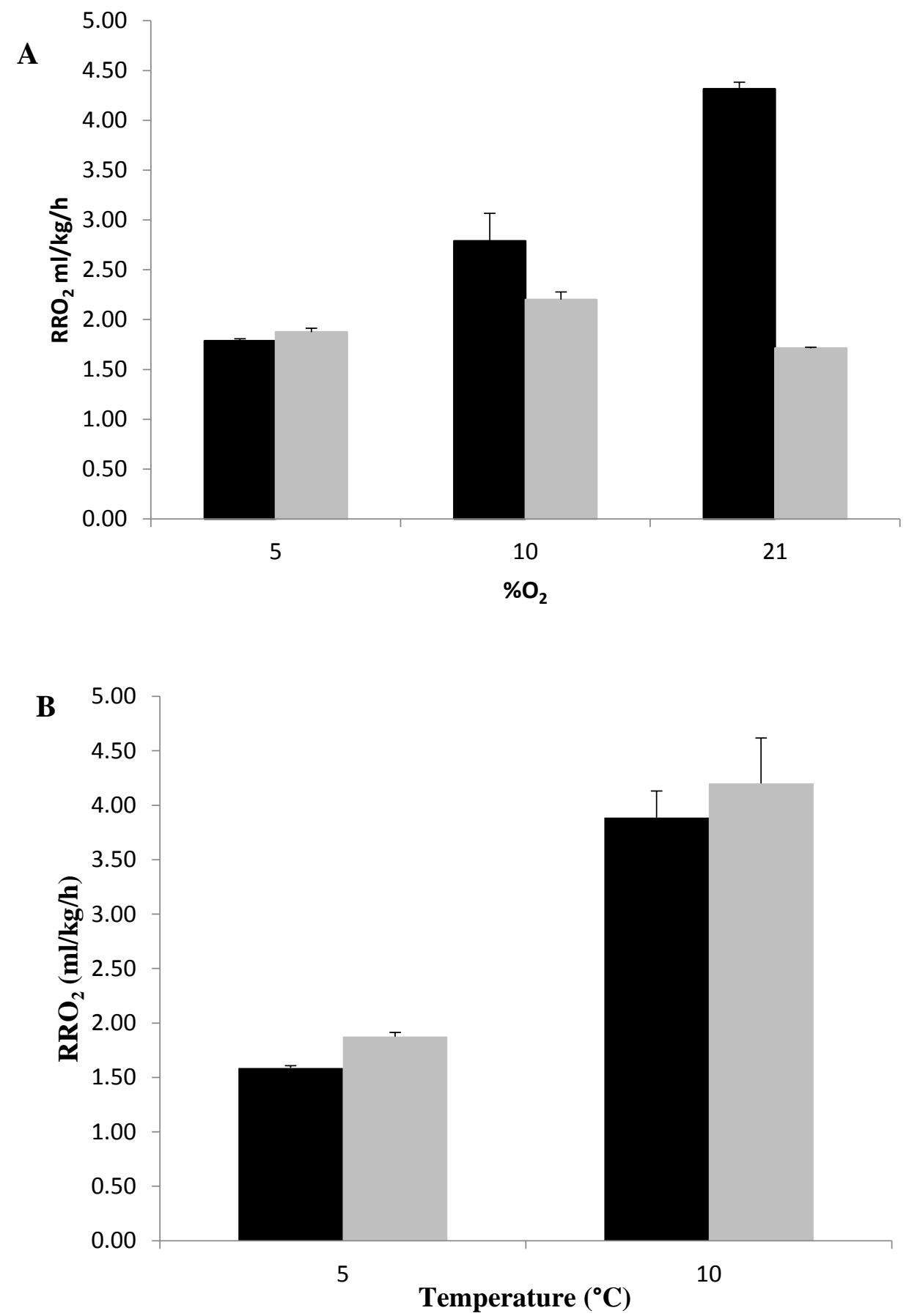

Figure 1. Respiration rate expressed as rate of oxygen consumption $\left(\mathrm{RRO}_{2}\right)$ of control sample $(\boldsymbol{\square})$ and coated sample $(\square)$ as function of oxygen concentrations at $5{ }^{\circ} \mathrm{C}(\mathbf{A})$ and as function of temperature at $5 \%$ of oxygen $(\mathbf{B})$.

\subsection{Shelf Life Evaluation}

\subsubsection{Headspace Gas Analysis}

Figure 2 shows the headspace gas composition of minimally processed apples stored at $5{ }^{\circ} \mathrm{C}$ for 14 days. As expected, the oxygen decreased during time whereas the carbon dioxide increased due to the respiration rate of the product and the permeability constant of the film. The oxygen changes from $21 \%$ to $6.6 \pm 0.2 \%$ for control samples, whereas for coated samples the equilibrium gas composition was reached after 4 days and the value of oxygen was $11.6 \pm 0.1$ (Figure 2A). Similar results were obtained 
for carbon dioxide (Figure 2B). The equilibrium values were reached after 4 days of storage for coated samples and after 7 days of storage for control samples. For control samples the $\mathrm{CO}_{2}$ reached a value of $10.4 \pm 0.4 \%$ whereas for coated samples the value was $7.2 \pm 0.5 \%$. These results can be justified by the reduction of respiration rate due to the presence of the coating, in agreement with the results reported in the previous paragraph.
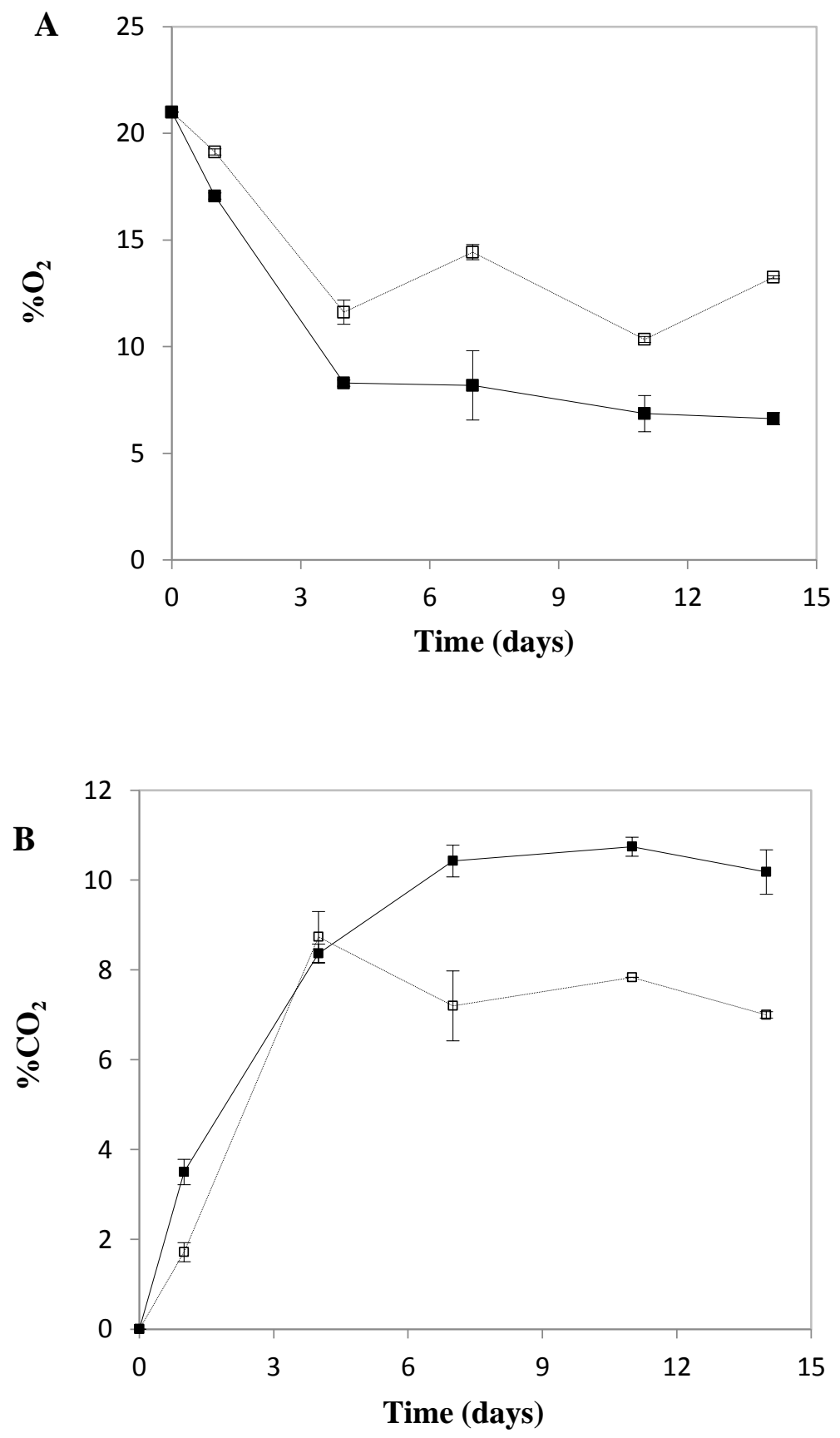

Figure 2. Headspace gas composition $\left(\mathrm{O}_{2} \%,(\mathbf{A}) ; \mathrm{CO}_{2} \%,(\mathbf{B})\right)$ of minimally processed apples stored at

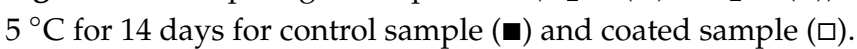

\subsubsection{Moisture Content, Color and $\mathrm{pH}$}

ANOVA analysis showed that the storage time and the coating did not have a significant effect on moisture content of minimally processed apples. The moisture content was constant and equal to $86 \%$. Table 1 reported the colorimetric parameters of the samples at different storage times. For control 
samples, $L^{*}$ decreased during storage from $80.6 \pm 0.5$ to $76.5 \pm 0.5$ after 14 days of storage with significant effect of time after 1 day of storage. The parameter $b^{*}$ increased from an initial value of $14.8 \pm 0.1$ to an equilibrium value after 1 day of storage of $17.8 \pm 0.3$. The parameter $\mathrm{a}^{*}$ remained almost constant $(-4.4 \pm 0.2)$ with slight variations during storage time, but without a clear trend up to 11 days of storage. After 14 days, the $\mathrm{a}^{*}$ value increased up to $-3.3 \pm 0.1$. The parameter $\Delta \mathrm{E}$ increased during time with significant variation since the first time of storage, reaching after 14 days a value of $7.8 \pm 0.1$.

Table 1. Color $\left(\mathrm{L}^{*}, \mathrm{a}^{*}, \mathrm{~b}^{*}, \Delta \mathrm{E}\right)$ and $\mathrm{pH}$ of control and coated samples at different storage time. $\mathrm{IQ}=$ quality index.

\begin{tabular}{|c|c|c|c|c|c|c|c|}
\hline Sample & IQ & \multicolumn{6}{|c|}{ Time (Days) } \\
\hline \multirow{3}{*}{ control } & $\mathrm{L}^{*}$ & $80.6 \pm 0.5 a$ & $75.7 \pm 0.5 b$ & $75.6 \pm 0.4 b$ & $75.8 \pm 0.6 c$ & $75.8 \pm 0.2 b c$ & $73.5 \pm 0.5 d$ \\
\hline & $b^{*}$ & $14.8 \pm 0.1 \mathrm{a}$ & $17.8 \pm 0.3 b$ & $17.61 \pm 0.09 b$ & $18.0 \pm 1.5 b$ & $18.6 \pm 0.5 b$ & $17.7 \pm 0.7 \mathrm{~b}$ \\
\hline & $\Delta \mathrm{E}$ & $0 \pm 0 \mathrm{a}$ & $5.6 \pm 0.2 b$ & $5.5 \pm 0.5 b$ & $6.8 \pm 0.1 c$ & $6.3 \pm 0.2 b c$ & $7.8 \pm 0.1 \mathrm{~d}$ \\
\hline \multirow{4}{*}{ coating } & $a^{*}$ & $-4.3 \pm 0.2 \mathrm{a}$ & $-4.8 \pm 0.2 \mathrm{a}$ & $-4.3 \pm 0.5 \mathrm{ab}$ & $-3.8 \pm 0.5 b c$ & $-3.76 \pm 0.07 b c$ & $-3.6 \pm 0.4 \mathrm{~d}$ \\
\hline & $b^{*}$ & $15.5 \pm 0.3 a$ & $16.9 \pm 0.8 b$ & $18 \pm 1 b c$ & $19 \pm 1 b c d$ & $20.2 \pm 0.5 \mathrm{~cd} *$ & $22.7 \pm 0.6 \mathrm{~d}$ * \\
\hline & $\Delta \mathrm{E}$ & $0 \pm 0 \mathrm{a}$ & $2.4 \pm 0.9 \mathrm{~b} *$ & $3 \pm 1 b *$ & $4 \pm 1 c *$ & $5.8 \pm 0.4 c$ & $8 \pm 1 d$ \\
\hline & $\mathrm{pH}$ & $3.54 \pm 0.02 a$ & $3.96 \pm 0.06 b^{*}$ & $4.08 \pm 0.08 b$ * & $4.21 \pm 0.06 c^{*}$ & $4.6 \pm 0.2 d^{*}$ & $4.94 \pm 0.04 \mathrm{e}$ \\
\hline
\end{tabular}

Different letters show a significant effect of time $(p<0.05) ;{ }^{*}$ significant effect of coating $(p<0.05)$.

The coating showed a significant effect on the color parameters $(p<0.05)$. In particular, in presence of coating the parameter $L^{*}$ decreased slightly reaching a value of $77 \pm 1$. The coating did not have any effect on the variation of the parameter $\mathrm{a}^{*}$, whereas it had a negative effect on the parameter $\mathrm{b}^{*}$ that increased up to a value of $22.7 \pm 0.6$ after 14 days of storage. However, the effect of the coating was significant on the parameter $\Delta \mathrm{E}$, assuring a slowly increasing of this parameter during storage time, with significant effect after 1, 4 and 7 days of storage. Figure 3 shows pictures of the samples after 1, 4, 7 and 11 days of storage. Also, from the image, it is possible to observe the protective effect of the coating on the appearance of minimally processed apples (Figure 3).
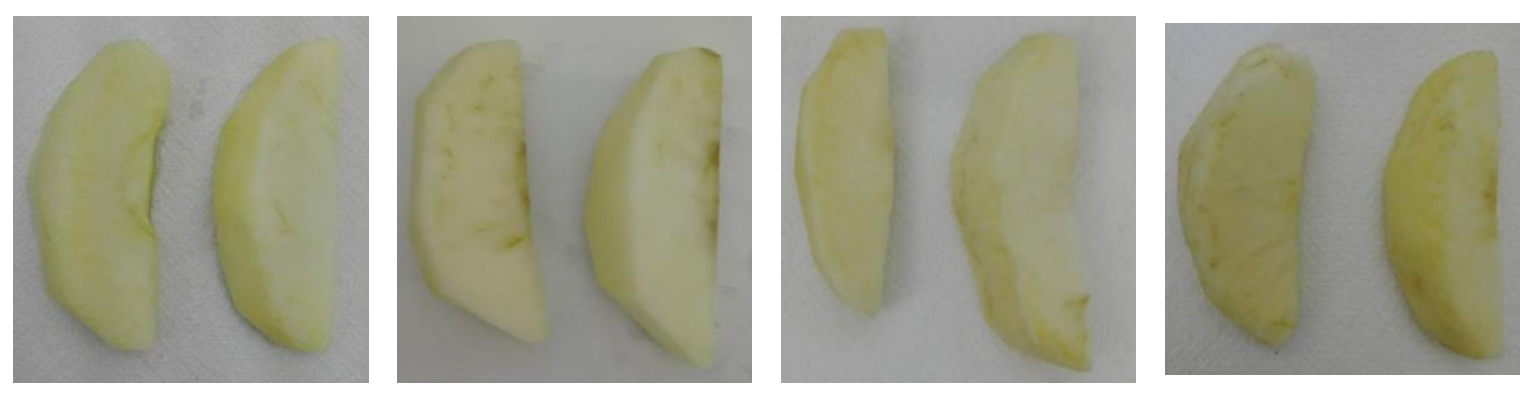

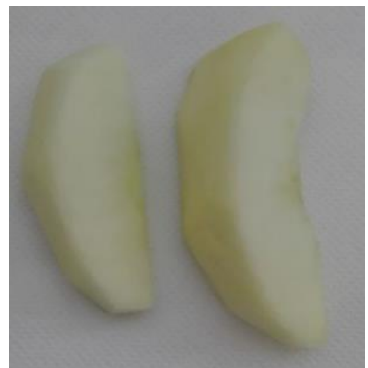

1 days

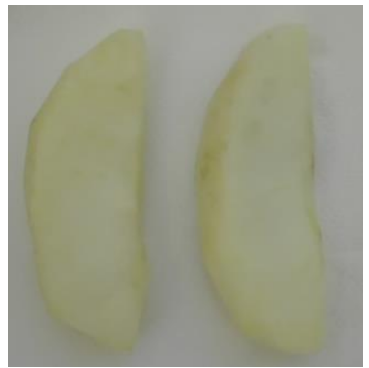

4 days

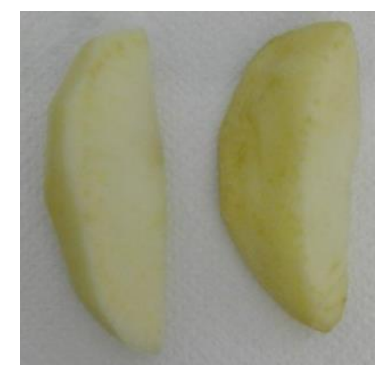

7 days

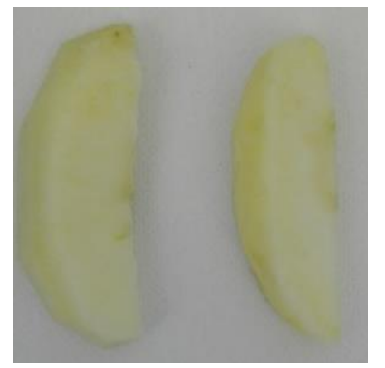

11 days

Figure 3. Color change of minimally processed apples during storage for 14 days at $5^{\circ} \mathrm{C}$. Control samples (high); coated sample (bottom). 
The $\mathrm{pH}$ of the samples increased during storage time from an initial value of $3.12 \pm 0.01$ to a value of $5.06 \pm 0.07$ for control samples (Table 1$)$. The coating has a significant effect on the $\mathrm{pH}(p<0.05)$ that increased slightly during storage time, with a significant effect after 1, 4, 7 and 11 days of storage.

\subsubsection{Mechanical Properties}

During storage time, the hardness of the minimally processed apples decreased from an initial value of $90 \pm 5 \mathrm{~N}$ to a final value of $76 \pm 2 \mathrm{~N}$ after 14 days of storage at $5{ }^{\circ} \mathrm{C}$. The coating helped to retard tissue softening during storage. The hardness remained almost constant during storage time (Figure 4). The ANOVA analysis reported a significant effect of the storage time and coating on the hardness parameter. The effect of the coating was significant at all the storage time $(p<0.05)$, except for the time, 11 days $(p>0.05)$. Data agreed with previous results where it was reported a protective effect of the coating on hardness when measured by penetration test [25]. Moreover, similar results were reported by [20] for Fuji apples coated with chitosan.

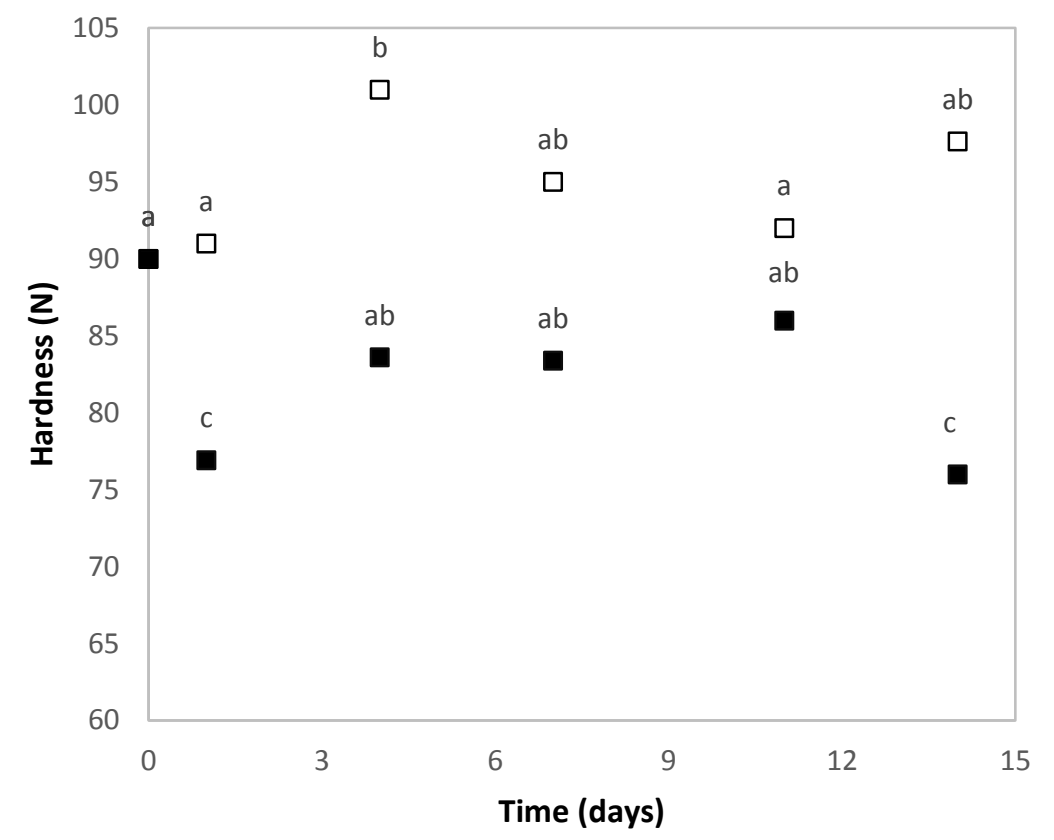

Figure 4. Hardness $(\mathrm{N})$ of minimally processed apples as function of storage time for samples stored 14 days at $4{ }^{\circ} \mathrm{C}$. Control sample (匹); coated sample ( $\left.\square\right)$. Different letters correspond samples significant effect due to time effect.

\subsubsection{Antioxidant Capacity}

Figure 5 shows the antioxidant capacity of minimally processed apples during storage at $5{ }^{\circ} \mathrm{C}$. Storage time $(p<0.05)$ and coating $(p<0.05)$ had a significant effect on TAA\% with significant interaction between factors $(p<0.05)$. The TAA $\%$ decreased from an initial value of $83 \%$ to a final value of $53 \%$ following a linear decrement. The rate of decrease was slower for coted samples respect to control samples, with significant different between the TAA \% values at all storage time except for the samples stored for 14 days of storage. A protective effect of CMC coating enriched with ascorbic acid and calcium chloride has been reported [22]. The protective effect of the coating can be justified by the barrier properties of the coating again oxygen which is an activation factor for oxidation reaction. Moreover, the lower respiration rate in presence of coating inhibits the establishment of an oxidative stress induced by fruit processing and senescence leading to less damage to biological membranes, and lower cell wall hydrolytic enzyme activity [29]. It has also been suggested that ascorbic acid can exert protection by acting as an oxygen scavenger, removing molecular oxygen and avoiding polyphenol oxidase-catalyzed reactions [30]. Thus, it is possible that the protective effect of 
the studied coating was due to a combination of contribution of the barrier properties of the coating, and antioxidant activity of the ascorbic acid.

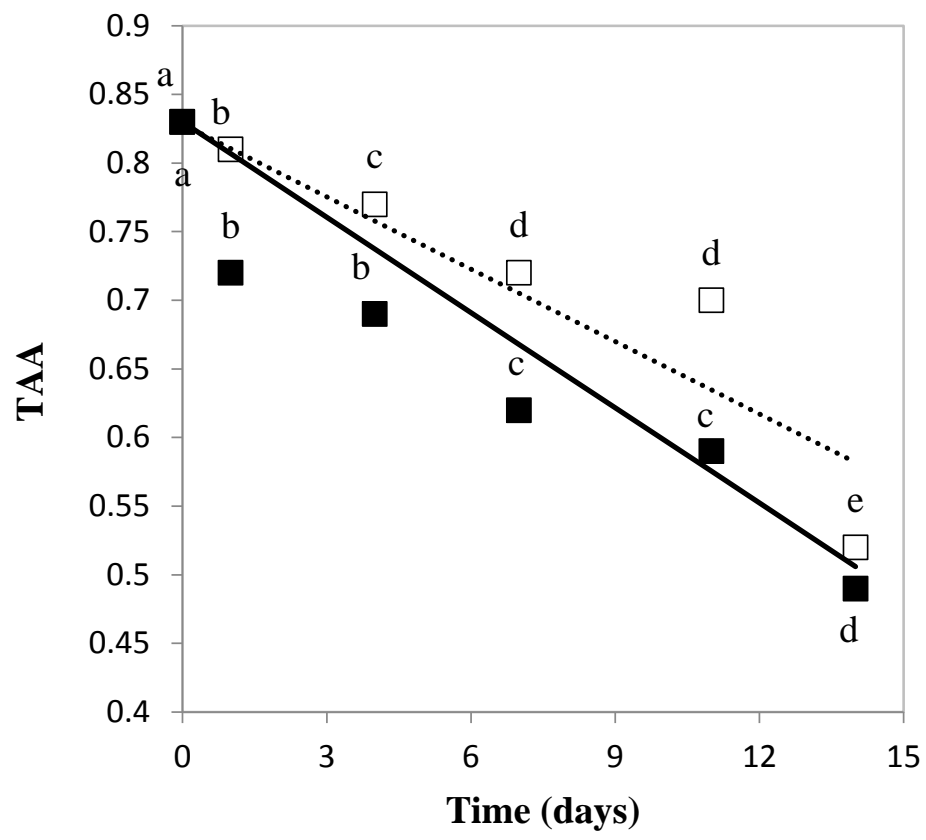

Figure 5. Antioxidant capacity as function of storage time for samples stored 14 days at $4{ }^{\circ} \mathrm{C}$. Control sample (匹); coated sample (). Different letters correspond samples significant effect due to time effect.

\section{Conclusions}

The results of the present work showed that chitosan-caseinate coating had a protective effect on respiration rate of minimally processed apples with positive impact of physiological parameters. By storage the coated sample in air, the reduction of the respiration rate is equivalent to the reduction obtained with $5 \%$ of oxygen. Thus, by using the coating technology the modified atmosphere technology can be avoided. Owing to the barrier properties of the coating to oxygen, a preservation of the antioxidant properties was also highlighted. As general trend by the shelf life study, the coating technologies extend the shelf life of the minimally processed apples from 7 days to 11 days at $5{ }^{\circ} \mathrm{C}$.

Author Contributions: Conceptualization, E.T. and S.C.; Methodology, E.T.; Formal Analysis, S.V.; Investigation, S.V., S.C., E.T.; Data Curation, S.V., and E.T.; Writing-Original Draft Preparation, E.T.; Writing-Review and Editing, S.V., and E.T.; Funding Acquisition, S.C.

Funding: This research was funded by the MIUR in the frame of the Prin project "Long Life, High Sustainability"-“Shelf Life Extension come indicatore di sostenibilità", 2012.

Acknowledgments: The first author acknowledges a Ph.D. scholarship from the University of Naples 'Federico II, Naples, Italy.

Conflicts of Interest: The authors declare no conflict of interest.

\section{References}

1. Bazzano, L.A. Dietary Intake of Fruit and Vegetables and Risk of Diabetes Mellitus and Cardiovascular Diseases; FAO/WHO Workshop on Fruit \& Vegetables for Health: Kobe, Japan, 2004.

2. Rolle, R.S.; Chism, G.W. Physiological consequences of minimally processed fruits and vegetables. J. Food Qual. 1987, 10, 157-177. [CrossRef]

3. Torrieri, E.; Langella, A.; Cavella, S.; Masi, P. Valutazione dei fenomeni di degradazione di mele fresche tagliate (Malus Communis Mill.) conservate in atmosfera protettiva. In Ricerche ed Innovazioni Nell'industria Alimentare, 6th ed.; Chirotti Editori: Pinerolo, Italy, 2003. 
4. Torrieri, E.; Di Monaco, R.; Cavella, S.; Masi, P. Fresh-cut Annurca apples: Acceptability study and shelf life determination. J. Sens. Stud. 2008, 23, 195-203. [CrossRef]

5. Rojas-Grau, M.A.; Sobrino-Lopez, A.; Tapia, M.S.; Martin-Belloso, O. Browning inhibition in fresh-cut Fuji apple slices by natural antibrowning agents. J. Food Sci. 2006, 71, 59-65. [CrossRef]

6. Ioannou, I.; Ghoul, M. Prevention of enzymatic browning in fruit and vegetables. Eur. Sci. J. ESJ 2013, 9, 30.

7. Watada, A.E.; Qi, L. Quality of fresh-cut produce. Postharvest Biol. Technol. 1999, 15, 201-205. [CrossRef]

8. Laurilia, E.; Kervinen, R.; Ahvenainen, R. The inhibition of enzymatic browning in minimally processed vegetables and fruits. Review article. Postharvest News Informat. 1998, 9, 53N-66N.

9. King, A.D., Jr.; Bolin, H.R. Physiological and microbiological storage stability of minimally processed fruits and vegetables. Food Technol. 1989, 43, 132.

10. Torrieri, E.; Di Monaco, R.; Cavella, S.; Masi, P. Determinazione della Shelf-Life della mela annurca confezionata in atmosfera protettiva. Ingred. Alim. 2009, 1, 15-20.

11. Gonzalez-Aguilar, G.A.; Valenzuela-Soto, E.; Lizardi-Mendoza, J.; Goycoolea, F.; Martinez-Tellez, M.A.; Villegas-Ochoa, M.A.; Monroy-Garcia, I.N.; Ayala-Zavala, J.F. Effect of chitosan coating in preventing deterioration and preserving the quality of fresh-cut papaya 'Maradol'. J. Sci. Food Agric. 2009, 89, 15-23. [CrossRef]

12. Porta, R.; Rossi-Marquez, G.; Mariniello, L.; Sorrentino, A.; Giosafatto, C.V.L.; Marilena Esposito, M.; Di Pierro, P. Edible Coating as Packaging Strategy to Extend the Shelf-life of Fresh-Cut fruits and vegetables. J. Biotechnol. Biomater. 2013, 3, 1-3. [CrossRef]

13. Yousuf, B.; Qadri, O.S.; Srivastava, A.K. Recent developments in shelf-life extension of fresh-cut fruits and vegetables by application of different edible coatings: A review. LWT Food Sci. Techol. 2018, 89, 198-209. [CrossRef]

14. Galus, S. Development of edible coating in the preservation of fruits and vegetables. In Polymers for Agri-Food Applications; Gutiérrez, T., Ed.; Springer: Cham, Switzerland, 2019.

15. Pacaphola, K.; Seraypheapc, K.; Aht-Ong, D. Development and application of nanofibrillated cellulose coating for shelf life extension of fresh-cut vegetable during postharvest storage. Carbohydr. Polym. 2019, 224, 115167. [CrossRef] [PubMed]

16. Chena, H.; Sunb, Z.; Yang, H. Effect of carnauba wax-based coating containing glycerol monolaurate on the quality maintenance and shelf-life of Indian jujube (Zizyphus mauritiana Lamk.) fruit during storage. Sci. Hortic. 2019, 244, 157-164. [CrossRef]

17. Patel, C.; Panigrahi, J. Starch glucose coating-induced postharvest shelf-life extension of cucumber. Food Chem. 2019, 288, 208-214. [CrossRef] [PubMed]

18. Gundewadia, G.; Gaur Rudra, S.; Jyoti Sarkar, D.; Singh, D. Nanoemulsion based alginate organic coating for shelf life extension of okra. Food Packag. Shelf Life 2018, 18, 1-12. [CrossRef]

19. Pan, S.Y.; Chen, C.H.; Lai, L.S. Effect of Tapioca Starch/Decolorized Hsian-Tsao Leaf Gum-Based Active Coatings on the of Fresh-Cut Apples. Food Bioprocess Technol. 2013, 6, 2059-2206. [CrossRef]

20. Qi, H.; Hu, W.; Jiang, A.; Tian, M.; Li, Y. Extending shelf-life of Fresh-cut 'Fuji' apples with chitosan-coatings. Innov. Food Sci. Emerg. Technol. 2011, 12, 62-66. [CrossRef]

21. Rojas-Grau, M.A.; Tapia, M.S.; Martin-Belloso, O. Using polysaccharide-based edible coatings to maintain quality of fresh-cut fuji apples. Food Sci. Technol. 2008, 41, 139-147. [CrossRef]

22. Saba, M.K.; Sogvar, O.B. Combination of carboxymethyl cellulose-based coatings with calcium and ascorbic acid impacts in browning and quality of fresh-cut apples. LWT Food Sci. Technol. 2016, 66, 165-171. [CrossRef]

23. Guerreiro, A.C.; Gago, C.M.L.; Faleiro, M.L.; Miguel, M.G.C.; Antunes, M.D.C. The effect of edible coatings on the nutritional quality of 'Bravo de Esmolfe' fresh-cut apple through shelf-life. LWT Food Sci. Technol. 2017, 75, 210-219. [CrossRef]

24. Özdemir, K.S.; Gökmen, V. Effect of Chitosan-Ascorbic Acid Coatings on the Refrigerated Storage Stability of Fresh-Cut Apples. Coatings 2019, 9, 503. [CrossRef]

25. Volpe, S.; Torrieri, E.; Cavella, S. Use of chitosan and chitosan-caseinate coating to prolong shelf life of minimally processed apples. Ital. J. Food Sci. 2018, 30, 30-35.

26. Torrieri, E.; Perone, N.; Cavella, S.; Masi, P. Modelling the respiration rate of minimally processed broccoli (Brassica rapa var. sylvestris) for modified atmosphere package design. Int. J. Food Sci. Technol. 2010, 45, 2186-2193. [CrossRef] 
27. Moreira, M.R.; Cassani, L.; Martín-Belloso, O.; Soliva-Fortuny, R. Effects of polysaccharide-based edible coatings enriched with dietary fiber on quality attributes of fresh-cut apples. J. Food Sci. Technol. 2015, 52, 7795-7805. [CrossRef] [PubMed]

28. Galus, S.; Kadzińska, J. Food applications of emulsion-based edible films and coatings. Trends Food Sci. Technol. 2015, 45, 273-283. [CrossRef]

29. Lopes, R.; Freitas, M.; Andrade, T.; Moita, W.; Carvalho, D.; Montenegro, I.; Moura, C.F.H.; Lopes, M.M.A.; De Miranda, A. Chitosan coating with trans-cinnamaldehyde improves structural integrity and antioxidant metabolism of fresh-cut melon. Postharvest Biol. Technol. 2016, 113, 29-39.

30. Rico, D.; Martin-Diana, A.B.; Barat, J.M.; Barry-Ryan, C. Extending and Measuring the Quality of Fresh-Cut Fruit and Vegetables: A Review. Trends Food Sci. Technol. 2007, 18, 373-386. [CrossRef]

(C) 2019 by the authors. Licensee MDPI, Basel, Switzerland. This article is an open access article distributed under the terms and conditions of the Creative Commons Attribution (CC BY) license (http://creativecommons.org/licenses/by/4.0/). 